\title{
Lactobacillus plantarum Exopolysaccharides Induce Resistance against Tomato Bacterial Spot
}

\author{
Juliane Mendes Lemos Blainski ${ }^{1}$, Argus Cesar da Rocha Neto ${ }^{1}$, Caroline Luiz ${ }^{1}$, Márcio José Rossi ${ }^{1}$ \\ \& Robson Marcelo Di Piero ${ }^{1}$ \\ ${ }^{1}$ Center of Agricultural Sciences, Federal University of Santa Catarina, Florianópolis, Santa Catarina, Brazil \\ Correspondence: Juliane Mendes Lemos Blainski, Center of Agricultural Sciences, Federal University of Santa \\ Catarina, Rodovia Admar Gonzaga, 1346-Itacorubi 88034-000 Florianópolis, Santa Catarina, Brazil. Tel: \\ 55-48-3721-5444. E-mail: juliane.lemos@yahoo.com.br
}

$\begin{aligned} & \text { Received: November 13, } 2016 \quad \text { Accepted: December 19, } 2016 \quad \text { Online Published: January 15, } 2017 \\ & \text { doi:10.5539/jas.v9n2p162 }\end{aligned}$ URL: http://dx.doi.org/10.5539/jas.v9n2p162

The research is financed by CAPES.

\begin{abstract}
Lactic acid bacteria produce several exopolysaccharides (EPS) that may have antimicrobial action and/or induce defense responses in plants. This work aims to evaluate the potential of EPS produced by Lactobacillus plantarum in the protection of tomato plants against bacterial spot caused by Xanthomonas gardneri, as well as to predict the possible mechanisms of action. The EPS were characterized through FTIR and applied at 0; 0.5; 1.5 and $3.0 \mathrm{mg} \mathrm{mL}^{-1}$ in tomato plants with five expanded leaves, followed by the pathogen inoculation after 3 or 7 days. Antimicrobial activity of the biopolymer $\left(1.5\right.$ or $\left.10.0 \mathrm{mg} \mathrm{mL}^{-1}\right)$ was evaluated in bioassay when EPS was incorporated into culture medium or embedded in antibiogram disk. The defense mechanisms i.e., total phenolic compounds and flavonoids content, phenylalanine ammonia-lyase (PAL), glutathione reductase (GR) and lipoxygenase (LOX) activities, were measured in tomato plants treated with EPS $\left(1.5 \mathrm{mg} \mathrm{mL}^{-1}\right)$, inoculated or not with $X$. gardneri. EPS reduced bacterial spot symptoms by up to $72.0 \%$ compared to the control. There were no direct effects of EPS on the in vitro growth of $X$. gardneri. The spectrophotometric profile, ascorbic and ellagic acid concentrations were change in tomato plants after EPS application, in plants challenged with the pathogen. Increases in PAL, GR and LOX activities were observed in plants treated with EPS. Thus, the application of $L$. plantarum exopolysaccharides can be considered as an effective alternative for controlling bacterial spot in tomato plants. This paper also discusses how these exopolysaccharides reduced the severity of the disease.
\end{abstract}

Keywords: Xanthomonas gardneri, Solanum lycopersicum, resistance induction, lactic acid bacteria

\section{Introduction}

Tomatoes (Solanum lycopersicum) are very important for human nutrition because of its high levels of mineral salts, vitamins and soluble sugars (Raiola et al., 2014). This crop contributes economically because its chain production employs a great number of people, in conventional and organic food production (Dimitri \& Oberholtzer, 2009; FAO, 2014). On the other hand, tomato plants are highly affected by several diseases that may restrict their yield, depending on the level of genetic resistance. In this sense, bacterial leaf spot caused by Xanthomonas sp. (X. euvesicatoria, X. gardneri, X. perforans and X. vesicatoria) is one of the major diseases affecting tomato plant growth, development and overall productivity (Jones et al., 2004; Quezado-Duval et al., 2007).

Bacterial leaf spot develops mainly in hot and rainy climate, since water favors the spread of the phytopathogen, as well as its infection and the colonization of plant tissues, reducing up to $50 \%$ of tomato crop yield (Quezado-Duval et al., 2007; Potnis et al., 2015). In favorable conditions, the progression of this disease is hard to control, even when specific strategies are adopted, e.g., the use of bacteria-free seeds or seedlings, the elimination of alternative hosts and the use of chemical control (Obradovic et al., 2004; Araujo et al., 2013; Potnis et al., 2015). Among the chemicals currently used for the pathogen control, antibiotics and copper-based 
compounds have variable efficiency, impairing plant development, causing damages to the environment and selecting bacteria resistant to the active ingredient (Silva \& Fay, 2006; Abbasi et al., 2014; Potnis et al., 2015).

One alternative to the conventional control of plant diseases may reside in the induction of resistance, where elicitors are applied in plants to activate genes that promote the synthesis of defense compounds, as the enzyme phenylalanine ammonia-lyase - PAL (Tian et al., 2006; Ge et al., 2013; Ebrahim et al., 2011; Salazar et al., 2013). The PAL is the first enzyme activated in the phenylpropanoid pathway, being responsible to the deamination of L-phenylalanine, transforming it into trans-cinnamic acid and ammonia. The trans-cinnamic acid can then be incorporated in different phenolic compounds, which are present in the formation of esters, coumarins, flavonoids, lignins and salicylic acid, among others. For example, while salicylic acid is normally associated with the induction of resistance by acting as a signal, ellagic and ascorbic acid act as antioxidants, protecting cell against oxidative damage (Gao et al., 2015; Tian et al., 2006; Zhang \& Zhou, 2010).

Similarly to the phenolic compounds, glutathione is involved in the process of cell protection against oxidative damage, being considered as an oxidative stress biomarker, and found as reduced glutathione (GSH) and oxidized glutathione (GSSG). The reduction of GSSG to GSH occurs by the activity of glutathione reductase (GR), where the increase of enzymatic activity indicates that the plant is under some stress and that the "glutathione apparatus" will provide greater tolerance to oxidative stress (Sharma \& Dubey, 2007; Sharma et al., 2012).

The jasmonic acid (JA) is also an important indicator related to stress, responsible to trigger several defense responses in plants, such as the synthesis of lipoxygenase (LOX). LOX is a key-enzyme that catalyzes the polyunsaturated fatty acids to hydro peroxides, resulting in reactive molecules, such as $\mathrm{H}_{2} \mathrm{O}_{2}$. The products of this pathway act in the plant development, in its defense against herbivores and pathogens, in detoxification reactions, among others (Feussner \& Wasternack, 2002).

In the search for compounds that can induce resistance and integrate the alternative control of plant diseases, polysaccharides such as $\beta$-glucans, chitins and chitosans present in the cell walls of fungi and yeasts, as well as exopolysaccharides (EPS) secreted by bacteria, are of interest because they are easily obtainable natural compounds (Wang et al., 2008; Mahapatra \& Banerjee, 2013; Leemhuis et al., 2013). Furthermore, plants are genetically prepared to sense microbial molecular signatures, called microbe-associated molecular patterns (MAMPs), activating immune responses (Zhang \& Zhou, 2010).

In general, lactic acid bacteria produce a large variety of EPS whose physical-chemical properties are unique (Notararigo et al., 2013). Species of the genus Lactobacillus, particularly L. plantarum, have been reported as important probiotic agents, bringing several benefits to human health, being also generally recognized as safe (GRAS) by the USFDA (Laws et al., 2001), and non-toxic to the environment (Seo et al., 2015). Exopolysaccharides can be recognized by plants, triggering different responses of defense. Moreover, the bioprocess involved to their obtainment is generally cheap and generates low impact to the environment. In this sense, the use of a microbiological approach to induce resistance in plants has a strong technological appeal and a high commercial potential due to the possibility of an accurate control of the production process, resulting in a stable, standardized and high-quality raw materials that are easily extracted and that can bring environmental advantages (Baque et al., 2012; Huang \& Mcdonald, 2009). In this study, we evaluated the efficacy of EPS extracted from L. plantarum to control bacterial spot and elicit defense mechanisms in tomato plants.

\section{Method}

\subsection{Lactobacillus Strain, Growth Conditions and Extraction of Exopolysaccharides}

L. plantarum (CCT 0580, ATCC 8014) was obtained from André Tosello Tropical Culture Collection (Campinas, Brazil). The bacterial suspension was prepared by adding $2 \mathrm{~mL}$ of an initial inoculum stored in sterile glycerol $2 \%$ into $20 \mathrm{~mL}$ of nutrient broth. Subsequently, the nutrient broth containing the inoculum was added into 200 $\mathrm{mL}$ of bean curd whey (BCW, Tofutura Indústria de Alimentos Ltda). $\mathrm{BCW}$ was supplemented with glucose $\left(11.5 \mathrm{~g} \mathrm{~L}^{-1}\right)$, yeast extract $\left(1 \mathrm{~g} \mathrm{~L}^{-1}\right)$, sodium citrate $\left(3 \mathrm{~g} \mathrm{~L}^{-1}\right)$, Tween $80\left(1 \mathrm{~mL} \mathrm{~L}^{-1}\right), \mathrm{KH}_{2} \mathrm{PO}_{4}\left(1 \mathrm{~g} \mathrm{~L}^{-1}\right), \mathrm{K}_{2} \mathrm{HPO}_{4}(1.4$ $\left.\mathrm{g} \mathrm{L}^{-1}\right), \mathrm{MgSO}_{4}\left(0.2 \mathrm{~g} \mathrm{~L}^{-1}\right), \mathrm{MnSO}_{4}\left(0.05 \mathrm{~g} \mathrm{~L}^{-1}\right)$. Each step of the experiment was performed at $30{ }^{\circ} \mathrm{C}$ for $18 \mathrm{~h}$. Furthermore, the production of L. plantarum EPS was performed in $\mathrm{BCW}$ in a 5-L airlift bioreactor. The production was conducted for $30 \mathrm{~h}$ and operated with a specific airflow rates, ranging from 0.2 to $1.3 \mathrm{vvm}$ (air volume per medium volume per minute). Temperature and $\mathrm{pH}$ were automatically maintained $\left(30^{\circ} \mathrm{C}, \mathrm{pH} 6.0\right)$. Polypropylene glycol $\left(0.4 \mathrm{~mL} \mathrm{~L}^{-1}\right)$ was used as an antifoaming agent.

The resultant microbial biomass was separated from the culture medium by centrifugation (2000 rpm, $20 \mathrm{~min}$ ), and the cell-free filtrate used to obtain the EPS through nanofiltration, condensation in a rotary-evaporator and 
lyophilization (Camelini et al., 2013). The EPS were analyzed by FTIR spectroscopy (ABD Bomem Inc. FTLA 2000), using KBr pellets. Protein content was determined by Bradford method, using BSA as reference.

\subsection{Xanthomonas Strain and Growth Conditions}

$X$. gardneri was provided by Sakata Seed Sudamerica LTDA and identified at the Centro Nacional de Pesquisa de Hortaliças (CNPH, EMBRAPA, Brazil) using BOX-PCR and the primer 5'-CTACGGCAAGGCGAC GCTGACG-3'. The bacteria were maintained at $25^{\circ} \mathrm{C}$ in phosphate buffer $\left(8.6 \mathrm{mM} \mathrm{K}_{2} \mathrm{HPO}_{4} ; 7.4 \mathrm{mM} \mathrm{KH}_{2} \mathrm{PO}_{4}\right)$. Periodic subcultures were replicated in Nutrient Agar (NA) culture medium [Composition $(\mathrm{g} / \mathrm{L}$ ): meat peptone 5.0; meat extract 3.0; agar 12.0] (Merck, Darmstadt, Germany) and the plates incubated at $25^{\circ} \mathrm{C}$, for $48 \mathrm{~h}$. The bacterial suspension was obtained by adding distilled water to the growth medium and spreading them with the aid of Drigalski spatula. The concentration of the suspensions was adjusted to $0.6\left(\mathrm{OD}_{600 \mathrm{~nm}}\right)$ (Coqueiro \& $\mathrm{Di}$ Piero, 2011; Luiz et al., 2012).

\subsection{Disease Severity Assay in Tomato Plants}

Commercial tomato seeds of Santa Cruz Kada cultivar (Paulista) were provided by Isla Sementes Ltda and sown in polystirene trays containing substrate Plantmax ${ }^{\circledR}$. Fifteen days after sowing, two plants were transferred to $2 \mathrm{~L}$ pots, filled with organic compost. Every 15 days, $20 \mathrm{~mL}$ of a solution containing $4.0 \mathrm{~g}$ of urea and $3.8 \mathrm{~mL}$ of Eurofit ${ }^{\mathbb{B}}$ per liter of distilled water was added to each pot. The experiments were conducted inside a greenhouse.

The EPS were sprayed on five-leaf tomato plants at the concentrations of $0.5,1.5$ and $3 \mathrm{mg} \mathrm{mL}^{-1}, 3$ days before the inoculation with $X$. gardneri. All leaves of each plant were sprayed with $10 \mathrm{~mL}$ of a suspension, using an HVLP paint gun (maximum pressure $=58 \mathrm{psi}, 0.7 \mathrm{~mm}$ nozzle, manufactured by Grifo, Italy) coupled to an air compressor (Schulz, Brazil; pressure $=25 \mathrm{lbf} / \mathrm{in} 2$; power $=180 \mathrm{~W}$; air flow $=105 \mathrm{~mL} \mathrm{~min}^{-1}$ ). After inoculation, the plants remained in a moist chamber for $60 \mathrm{~h}$, in order to favor the bacterium development.

After the most effective EPS concentration was established $\left(1.5 \mathrm{mg} \mathrm{mL}^{-1}\right)$, the time interval between plant treatment and inoculation was evaluated, being investigated the intervals of 3 and 7 days. Two experiments were conducted in greenhouse, under different environmental conditions: the average temperature of the first experiment was $28 \pm 2{ }^{\circ} \mathrm{C}$, whereas in the second, it was $19.8 \pm 1{ }^{\circ} \mathrm{C}$. All plants were treated and inoculated as described previously, and all experiments were set up under a completely randomized design, with seven replications per treatment, where a pot containing two plants represented a repetition. The assessment of disease severity was performed 15 days after the inoculation, with the aid of a diagrammatic scale for bacterial spot described by Mello et al. (1997). For these experiments, distilled water and the commercially available resistance inducer, Acibenzolar-S-Methyl (ASM), $0.05 \mathrm{mg} \mathrm{mL}^{-1}$, were used as negative and positive control, respectively. ASM was obtained from the commercial product Bion ${ }^{\circledR}$ (Syngenta Proteção de Cultivos Ltda., Brazil).

\subsection{Determination of Antibiotic Activity}

The EPS were prepared and incorporated into NA culture medium $\left(1.5 \mathrm{mg} \mathrm{mL}^{-1}\right)$. The mixture was placed in 8 $\mathrm{cm}$ Petri dishes, and $100 \mu \mathrm{L}$ of the bacterial suspension $\left(0.1 \mathrm{OD}_{600 \mathrm{~nm}}\right.$, diluted to $\left.1 / 1000\right)$ pipetted over the surface and spread with the aid of a Drigalski spatula. NA without EPS was used as control. The plates were incubated $\left(25 \pm 1{ }^{\circ} \mathrm{C}, 48 \mathrm{~h}\right)$ and the evaluation performed counting the number of colony-forming units (CFU) (adapted from Luiz et al., 2012).

An antibiogram bioassay was also performed. For this, $50 \mu \mathrm{L}$ of a bacterial suspension $\left(0.3 \mathrm{OD}_{600 \mathrm{~nm}}\right.$, diluted to $1 / 1000)$ were spread in NA plates, and left drying. Then, paper discs ( $5 \mathrm{~mm}$ diameter) were soaked with $10 \mu \mathrm{L}$ of a suspension containing EPS $\left(10 \mathrm{mg} \mathrm{mL}^{-1}\right)$, distilled water or the antibiotic oxytetracycline $\left(10 \mathrm{mg} \mathrm{mL}^{-1}\right)$. Five replications were made for each treatment, where a replication was represented by a single plate containing four disks. The plates were incubated at $25 \pm 1{ }^{\circ} \mathrm{C}$ for $48 \mathrm{~h}$ and the evaluation performed by analyzing the formation of a bacterial growth inhibition halo.

\subsection{Biochemical Analyses}

EPS (1.5 mg mL $\left.{ }^{-1}\right)$, ASM $\left(0.05 \mathrm{mg} \mathrm{mL}^{-1}\right)$ or distilled water (control) were applied on tomato plants with five true leaves. At the 3th day after application, the inoculation was performed with bacterial suspension of $X$. gardneri (OD 0.6; $600 \mathrm{~nm}$ ). Leaf samples were collected at 3, 5 and 7 days after spraying the treatments. The second, third and fourth leaves were sampled. Five replications for each treatment were made. The collected samples were stored in transparent plastic bags, put in contact with liquid nitrogen, and subsequently stored in ultra-freezer $\left(-80^{\circ} \mathrm{C}\right)$, until processing time. The samples were processed for evaluation of spectrophotometric profile, quantification of total phenolic compounds and flavonoids, identification of phenolic compounds through HPLC, as well as for the determination of enzymatic activity of phenylalanine ammonia-lyase (PAL), glutathione reductase (GR) and lipoxygenase (LOX). 
2.5.1 Spectrophotometric Profile, Quantification of Total Phenolic Compounds and Flavonoids and Identification of Phenolic Compounds through HPLC

For the spectrophotometric profile, leaf samples $(250 \mathrm{mg})$ were homogenized in $5 \mathrm{~mL}$ ethanol-toluene $(1: 1 ; \mathrm{v} / \mathrm{v})$, with the aid of a mortar for $3 \mathrm{~min}$, and left standing for $15 \mathrm{~min}$. The extracts were diluted in ethanol-toluene (1:5; $\mathrm{v} / \mathrm{v}$ ) and the absorbance scanned spectrophotometrically $(250$ to $750 \mathrm{~nm})$. A scan was performed for each sample and the results were expressed by the mean absorbance values of three replications.

In order to quantification of total phenolic compounds, flavonoids and identification of phenolic compounds through HPLC, $200 \mathrm{mg}$ of the foliar tissue of each sample were crushed in a porcelain pestle with liquid nitrogen, and homogenized with $3 \mathrm{~mL}$ of $80 \%$ acidified methanol (methanol: $\mathrm{HCl}=80: 1, \mathrm{v} / \mathrm{v}$ ). The resulting mixture was incubated in dark for $1 \mathrm{~h}$, at room temperature, and subsequently centrifuged ( $3000 \mathrm{~g}, 5 \mathrm{~min})$, recovering the supernatant for the subsequent analysis.

The phenolic compounds were performed according of McCue et al. (2000), with modifications. Firstly, $0.5 \mathrm{~mL}$ of the obtained extract was mixed with $0.5 \mathrm{~mL}$ of methanol $(95 \%)$. Then, $1 \mathrm{~mL}$ of ethanol $(95 \%), 1 \mathrm{~mL}$ of distilled water and $0.5 \mathrm{~mL}$ of Folin-Ciocalteau were added to this mixture. After $5 \mathrm{~min}, 1 \mathrm{~mL}$ of $\mathrm{Na}_{2} \mathrm{CO}_{3}(5 \%)$ was added, and the sample was incubated in the dark for another $1 \mathrm{~h}$. The absorbance of the final solution was measured at $725 \mathrm{~nm}$ using a spectrophotometer and the quantification of phenolic compounds calculated based on a gallic acid standard curve $(0.0-100 \mu \mathrm{g})$. The results were expressed in $\mu \mathrm{g}$ of gallic acid equivalents per gram of fresh weight $\left(\mu \mathrm{g} \mathrm{EAG} \cdot \mathrm{g} \cdot \mathrm{FW}^{-1}\right)$.

For the flavonoid quantification, $0.5 \mathrm{~mL}$ of the crude extract was added with $2.5 \mathrm{~mL}$ of ethanol $(99 \%)$ and 0.5 $\mathrm{mL}$ of methanol solution of aluminum chloride $(2 \%)$, and left $1 \mathrm{~h}$ in darkness. The absorbance was measured at $420 \mathrm{~nm}$ and flavonoid content was expressed in $\mu \mathrm{g}$ of quercetin equivalents per $\mathrm{g}$ of fresh weight $(\mu \mathrm{g}$ $\left.\mathrm{EQ} \cdot \mathrm{g} \cdot \mathrm{FW}^{-1}\right)$.

For the identification of phenolic compounds through HPLC, aliquots $(10 \mu \mathrm{L})$ of the crude extract were injected into liquid chromatography equipment (Thermo Scientific Dionex UltiMate 3000) equipped with a reverse phase column $\left(\mathrm{C}_{18}\right.$ reverse phase; Phenomenex LC-18, $250 \mathrm{~mm} \times 4.6 \mathrm{~mm}, 5 \mu \mathrm{m} \varnothing$ inner; $\left.40{ }^{\circ} \mathrm{C}\right)$ and a spectrophotometric detector UV-visible $(\lambda=280 \mathrm{~nm})$. A solution of acidified water $(\mathrm{pH} 3.0)$ and methanol PA $(85: 15 \mathrm{v} / \mathrm{v})$, in a flow of $1 \mathrm{~mL} \mathrm{~min}{ }^{-1}$, was used as mobile phase. The identification of the compounds of interest was performed through the comparison between the samples retention times with the retention times of standard compounds (ascorbic acid, ellagic acid, gallic acid, epicatechin, gallocatechin, caffeic acid, rutin). The quantification of the phenolic acids was performed using the standard curves of the major compound (ascorbic acid). The results were expressed in $\mu \mathrm{g}$ per $\mathrm{g}$ of fresh weight $\left(\mu \mathrm{g} \cdot \mathrm{g} \cdot \mathrm{FW}^{-1}\right)$ and refer to the average of three consecutive injections for each sample $(\mathrm{n}=3)$.

\subsubsection{Determination of Phenylalanine Ammonia-lyase Activity}

Sampled leaf tissue $(100 \mathrm{mg})$ was homogenized in sodium borate buffer $(25 \mathrm{mM}, \mathrm{pH} 8.8)$ containing ethylene diamine tetra-acetic acid (EDTA, $1 \mathrm{mM}$ ) and polyvinylpyrrolidone (PVP, $0.5 \%$ ) for determining phenylalanine ammonia-lyase activity. The obtained solution was centrifuged $\left(20,000 \mathrm{~g}, 30 \mathrm{~min}, 4{ }^{\circ} \mathrm{C}\right)$ and the supernatant (protein extract) recovered. The enzymatic activity was determined according to Falcón et al. (2008), with modifications. Fifty $\mathrm{mM}$ of phenylalanine was added to $100 \mathrm{mM}$ sodium borate buffer ( $\mathrm{pH} 8.8$ ). Then, a total of $250 \mu \mathrm{L}$ of protein extract was added to $250 \mu \mathrm{L}$ to the previous mixture, and incubated at $40{ }^{\circ} \mathrm{C}$ for $1 \mathrm{~h}$. The reaction was interrupted by the addition of $200 \mu \mathrm{L}$ of $5 \mathrm{~N} \mathrm{HCl}$ and ice bath for $5 \mathrm{~min}$. Subsequently, $300 \mu \mathrm{L}$ of distilled water were added, and the absorbance of the final solution was measured at $290 \mathrm{~nm}$. The results were expressed in nmol of trans-cinnamic acid formed per mg of protein per minute of reaction (nmol trans-cinnamic acid $\mathrm{min}^{-1} \cdot \mathrm{mg}$ protein).

\subsubsection{Glutathione Reductase and Lipoxygenase Activity}

Leaf samples $(100 \mathrm{mg})$ were macerated in liquid nitrogen, and added $1.5 \mathrm{~mL}$ of Tris-HCl buffer $(50 \mathrm{mM})$ with $\mathrm{CaCl}_{2}(20 \mathrm{mM}), \mathrm{pH}$ 8.0. The resultant extract was centrifuged $\left(5.500 \mathrm{~g}, 10 \mathrm{~min}, 4{ }^{\circ} \mathrm{C}\right)$, and the supernatant recovered. The glutathione reductase (GR) activity was determined according to the method described by Calrberg e Mannervick (1985) while lipoxygenase activity (LOX) of linoleic acid was determined according to the method described by Axelrod et al. (1981).

The GR activity was determined by adding $50 \mu \mathrm{L}$ of the obtained extract to $250 \mu \mathrm{L}$ of reaction buffer (Tris- $\mathrm{HCl}$ buffer; $0.10 \mathrm{M}, \mathrm{pH} 7.5)$, magnesium chloride $(0.3 \mathrm{mM})$, glutathione oxidized (GSSG; $1.0 \mathrm{mM}$ ), and NADPH $(0.20 \mathrm{mM})$. The decrease in the absorbance was measured over the first minute of the reaction $\left(340 \mathrm{~nm}, 28^{\circ} \mathrm{C}\right)$ 
and the results expressed in GR units $\mathrm{min}^{-1} \cdot \mathrm{mg}$ protein ${ }^{-1}$, where 1 unit of GR was considered the quantity of the enzyme necessary to reduce 0.01 absorbance units.

For LOX activity, $5 \mu \mathrm{L}$ of the obtained extract was added with $20 \mu \mathrm{L}$ of sodium linoleate $(10 \mathrm{mM})$, previously prepared in $250 \mu \mathrm{L}$ phosphate buffer $(50.0 \mathrm{mM}, \mathrm{pH} 6.5)$. The rate of the reaction was determined at every 20 seconds interval $\left(234 \mathrm{~nm}, 2 \mathrm{~min}, 40^{\circ} \mathrm{C}\right.$ ). The results were expressed in LOX units $\mathrm{min}^{-1} \cdot \mathrm{mg}^{\circ}$ protein ${ }^{-1}$, where 1 unit of LOX was considered the quantity of enzyme required to reduce 0.01 absorbance units.

For all samples, the amount of total protein was evaluated accordingly to the method described by Bradford (1976).

\subsection{Statistical Analyses}

The statistical analysis of variance (one-way or factorial ANOVA) and Tukey`s test were performed to verify the differences between the means of the analysed variables in the experiments. When necessary, the regression analysis was performed to verify the effect of treatment doses (quantitative factor). The analyses were performed using the statistical software Statistica 8.0 (Statsoft, 2007) and SISVAR (Ferreira, 2003).

\section{Results}

\subsection{Characterization of the EPS, Their Protective and Antimicrobial Effects}

The infrared spectroscopy allowed the identification of the typical functional groups of the studied biopolymer (Figure 1). It showed an intense band in the region of $3.425 \mathrm{~cm}^{-1}$, relative to the $\mathrm{O}-\mathrm{H}$ stretch, while in the region of $2.931 \mathrm{~cm}^{-1}$ the band refers to the $\mathrm{C}-\mathrm{H}$ stretch. The band in the region of $1.650 \mathrm{~cm}^{-1}$ showed a potential presence of $\mathrm{C}=\mathrm{C}$ groups in the structure of the carbohydrate. Additionally, the bands in the regions of 1.413, 1.338 and $1.020 \mathrm{~cm}^{-1}$ indicate a C-C stretch, a C-O bend, and a C-O-C stretch, respectively.

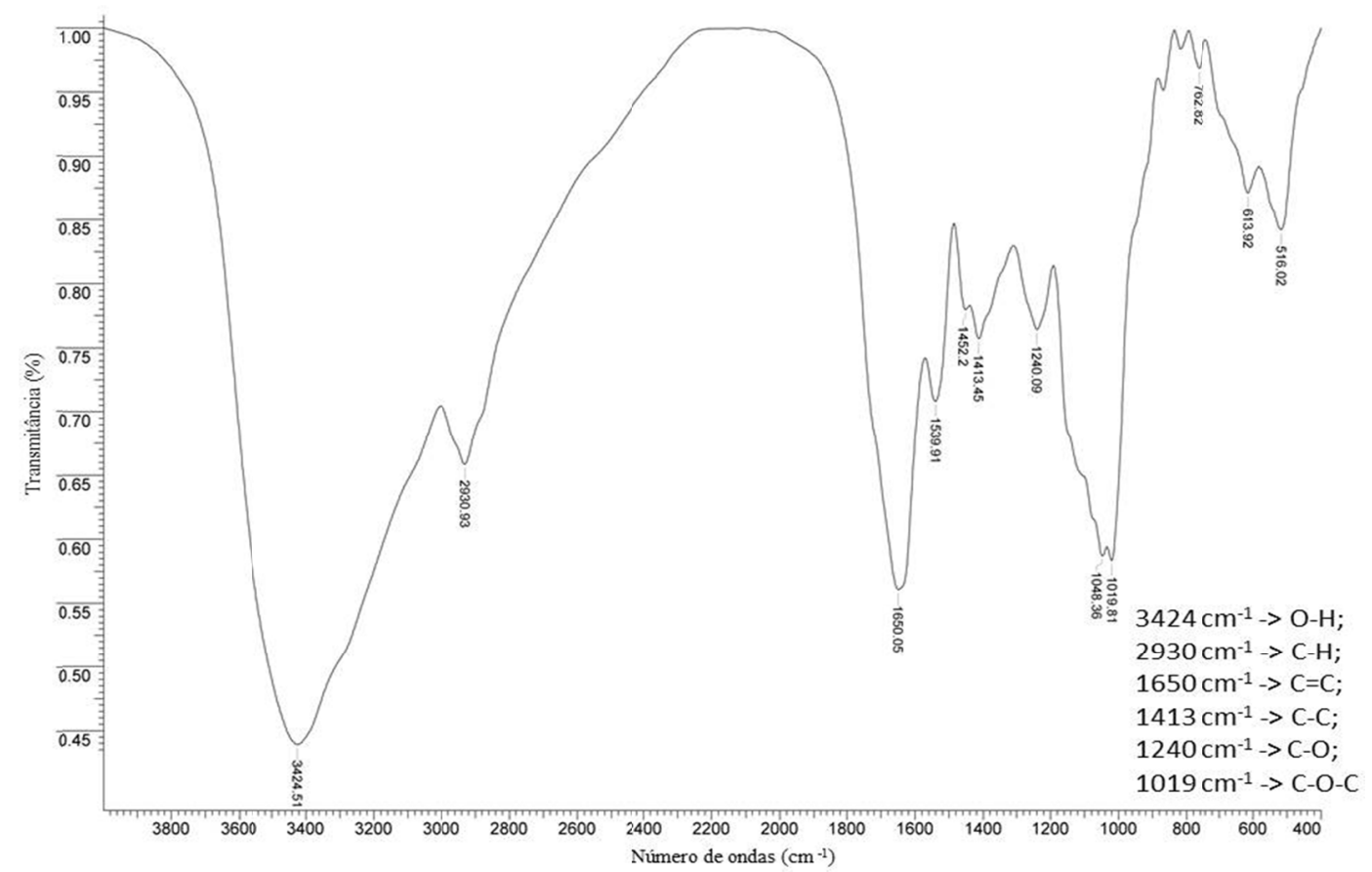

Figure 1. Infrared spectrum of the EPS produced by Lactobacillus plantarum, in the region of $4.000-400 \mathrm{~cm}^{-1}$, using $\mathrm{KBr}$ pellets

It was observed an effect of EPS doses against the severity of bacterial spot in tomato plants 3 days after the treatments application (Figure 2). Nine days after X. gardneri inoculation, a reduction of $52 \%, 72 \%$ and $63 \%$ on the severity of the disease was observed when the EPS was applied on the leaves at concentrations $0.5,1.5$ and $3.0 \mathrm{mg} \mathrm{mL}^{-1}$, respectively. Eighteen days after the inoculation, the protection levels reached $42 \%, 54 \%$ and $58 \%$, respectively. Distinctively, ASM decreased the symptoms of bacterial spot by approximately $93.0 \%$. 
After verified the best concentration of EPS against bacterial spot in tomato plants, an assay was performed to determine the best time interval between the application of the treatments and the inoculation with $X$. gardneri (3 or 7 day-interval) (Table 1). It was observed an interaction between the variables in both experiments. The EPS $\left(1.5 \mathrm{mg} \mathrm{mL}^{-1}\right)$ controlled the disease when applied 3 days before the inoculation of the pathogen. However, this efficiency was reduced when a 7 day interval was used. Furthermore, it was observed that the ASM provided higher disease control independent of time interval between the application of the product and the pathogen inoculation, in both experiments.

The EPS did not inhibit the in vitro growth of $X$. gardneri (Table 2). In the assays where EPS were incorporated to the culture medium (NA), no significant difference was observed in the number of colonies of $X$. gardneri, compared to control. This result was further confirmed by the disk diffusion test (antibiogram), which showed that the EPS did not reduce the growth of $X$. gardneri. An inhibition halo $(1 \mathrm{~cm})$ only appeared in the bactericide (tetracycline) used as control.

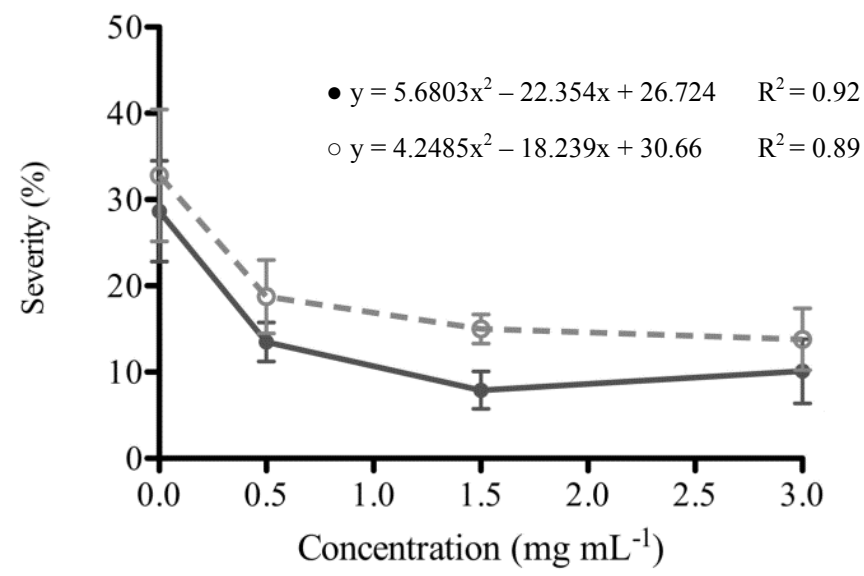

Figure 2. Bacterial leaf spot severity in tomato plants treated with the EPS of Lactobacillus plantarum (0; 0.5;

1.5 and $\left.3.0 \mathrm{mg} \mathrm{mL}^{-1}\right) 3$ days before the inoculation with Xanthomonas gardneri. The assessment of disease severity was performed at 9 and 18 days after inoculation $\left(1^{\text {st }}\right.$ and $2^{\text {nd }}$ assessment $)$. There was a significant effect of doses according to the F-test $(\mathrm{p}<0.05)$. Bars represent the mean \pm standard deviation

Table 1. Bacterial leaf spot severity in tomato plants submitted to different time intervals ( 3 and 7 days) between the application of the EPS of Lactobacillus plantarum (EPS Lac), Acibenzolar-S-Methyl (ASM) or distilled water, and the inoculation with Xanthomonas gardneri. Assessments performed at 15 days after inoculation

\begin{tabular}{llllll}
\hline & \multicolumn{3}{c}{ Severity (\%) } \\
\cline { 2 - 3 } \cline { 5 - 6 } & \multicolumn{2}{c}{ Experiment 1 } & & \multicolumn{2}{c}{ Experiment 2 } \\
\cline { 2 - 3 } \cline { 5 - 6 } Water & $40.23 \pm 2.91 \mathrm{Aa}$ & $40.62 \pm 6.63 \mathrm{Aa}$ & & $21.58 \pm 2.01 \mathrm{Aa}$ & $20.00 \pm 1.26 \mathrm{Aa}$ \\
EPS Lac & $19.76 \pm 5.19 \mathrm{Bb}$ & $35.69 \pm 6.31 \mathrm{Aa}$ & & $13.67 \pm 2.16 \mathrm{Bb}$ & $18.75 \pm 3.06 \mathrm{Aa}$ \\
ASM & $7.14 \pm 4.06 \mathrm{Ca}$ & $6.71 \pm 4.23 \mathrm{Ba}$ & & $0.85 \pm 0.53 \mathrm{Ca}$ & $0.71 \pm 0.33 \mathrm{Ba}$ \\
\hline
\end{tabular}

Note. Means followed by the same capital letters in the column and lower case letters in the line, do not differ statistically by the Tukey test $(\mathrm{p}<0.05)$. 
Table 2. Effect of the EPS of Lactobacillus plantarum incorporated to a culture medium or added in antibiogram disks on the growth of Xanthomonas gardneri. Assessment of the number of colony forming units (CFU) and diameter of the bacterial growth inhibition halo after $48 \mathrm{~h}$ of incubation

\begin{tabular}{llllll}
\hline & \multicolumn{2}{c}{ Number of CFU } & & \multicolumn{2}{c}{ Growth inhibition halo (cm) } \\
\cline { 2 - 3 } \cline { 5 - 6 } & Experiment 1 & Experiment 2 & & Experiment 1 & Experiment 2 \\
\hline Water & $120,5 \pm 3,9^{\text {ns }}$ & $159,3 \pm 2,1^{\text {ns }}$ & & 0 & 0 \\
EPS Lac & $124,5 \pm 3,2$ & $154,9 \pm 3,5$ & & 0 & 0 \\
Oxytetracycline & - & - & & 1,0 & 1,0 \\
\hline
\end{tabular}

Note. ${ }^{\text {ns }}$ Not significative statistically $(\mathrm{p}<0.05)$.

3.2 Changes in the Spectrophotometric Profiles, Phenolic Compounds and Flavonoid Content in Plants Treated with the EPS

Changes in the spectrophotometric profiles of plants treated at different time intervals were observed (Figure 3).
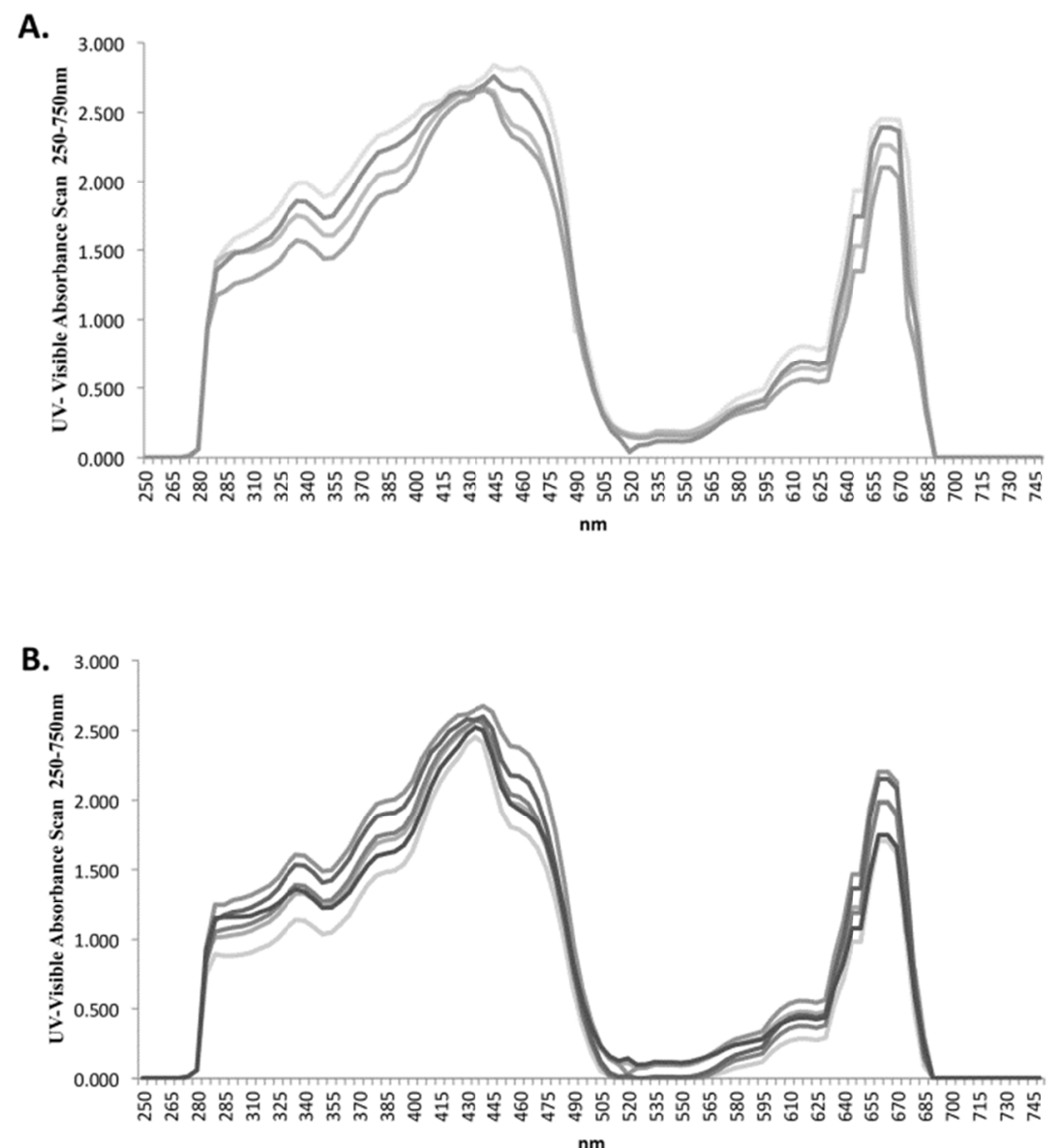


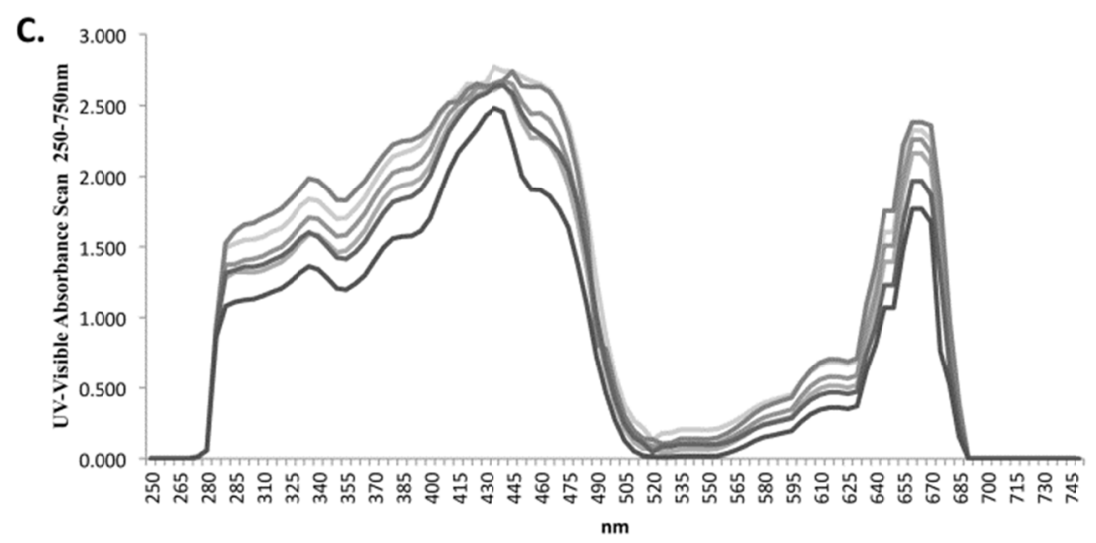

Figure 3. The spectrophotometric profile of ethanol-toluene extract of tomato plants treated with the EPS of Lactobacillus plantarum (EPS Lac), Acibenzolar-S-Methyl (ASM) and distilled water, from plants inoculated (Inoc) or not (NI) with Xanthomonas gardneri, at 3 (A), 5 (B) and 7 (C) days after the treatments (dat). A. (-) Water, $(-)$ EPS Lac and (-) ASM; B. and C. ( ) Water Inoc, $(-)$ EPS Lac Inoc, $(-)$ ASM Inoc, $(-)$ Water

$$
\text { NI, (一) EPS Lac NI and (-) ASM NI }
$$

At the 3rd and 7th days after the treatments, a significant decrease in the absorbance in the bands $285-325 \mathrm{~nm}$ in plants treated with the EPS, inoculated or not, was observed when compared to control. At 5 days after the treatments (dat), plants that have been sprayed with ASM and inoculated, showed a slight increase in the absorbance within this range. At 7 dat, plants treated with ASM, inoculated or not, showed significant reduction in absorbance, similar to those treated with EPS (Table 3).

No significative variations were observed in the content of total phenolic compounds over time in plants treated with the EPS, distilled water or ASM. Even after the inoculation of the pathogen, the evaluated parameters remained unchanged (Figure 4A). In a different manner, the flavonoids content increased at 7 dat, after the inoculation with $X$. gardneri, independently of the treatment, whereas plants previously sprayed with ASM showed minor changes (Figure 4B).

The HPLC results revealed a similar profile for all samples. Two compounds were identified and quantified (ascorbic acid and ellagic acid), being observed a significant difference in their concentration between treatments over time (Figure 5). At 5 dat, it was observed that among the plants not inoculated, those treated with ASM showed the highest concentrations of ascorbic acid, i.e., approximately $30 \%$ more than the control. In this same period, EPS and ASM decreased by 30 and 34\%, respectively, the concentration of ascorbic acid in inoculated plants (Figure 5A).

Table 3. Average values of absorbance in the range between 285-325 nm in tomato plants treated with the EPS of Lactobacillus plantarum (EPS Lac), Acibenzolar-S-Methyl (ASM) or distilled water, from plants inoculated (Inoc) or not (NI) with Xanthomonas gardneri, at 3, 5 and 7 days after treatment (dat)

\begin{tabular}{|c|c|c|c|c|c|}
\hline \multirow{3}{*}{ Treatments } & \multicolumn{5}{|c|}{ Absorbance 285-325 nm } \\
\hline & \multirow{2}{*}{3 dat (before Inoc) } & \multicolumn{2}{|c|}{5 dat (2DAI) } & \multicolumn{2}{|c|}{7 dat (4DAI) } \\
\hline & & $\mathbf{N}$ I & Inoc & $\mathbf{N} \mathbf{I}$ & Inoc \\
\hline Water & $1.44 \pm 0.08 \mathrm{~A}$ & $1.09 \pm 0.01 \mathrm{Ab}$ & $0.90 \pm 0.06 \mathrm{Aa}$ & $1.60 \pm 0.05 \mathrm{Aa}$ & $1.51 \pm 0.02 \mathrm{Aa}$ \\
\hline EPS Lac & $1.25 \pm 0.02 \mathrm{~B}$ & $1.19 \pm 0.05 \mathrm{Ab}$ & $1.05 \pm 0.02 \mathrm{Aa}$ & $1.33 \pm 0.05 \mathrm{Ba}$ & $1.30 \pm 0.14 \mathrm{Ba}$ \\
\hline ASM & $1.44 \pm 0.06 \mathrm{~A}$ & $1.15 \pm 0.04 \mathrm{Aa}$ & $1.27 \pm 0.04 \mathrm{Bb}$ & $1.12 \pm 0.02 \mathrm{Ca}$ & $1.39 \pm 0.02 \mathrm{Bb}$ \\
\hline
\end{tabular}

Note. 5 and 7 dat correspond to 2 and 4 days after inoculation (DAI). Means followed by the same capital letters in the column and lower case letters in the line, do not differ statistically by the Tukey test $(p<0.05)$ on time interval.

The concentration of ascorbic acid was also different at 7 dat (Figure 5B). Plants sprayed with EPS or ASM, both non-inoculated, showed a reduction in the phenolic concentration (50 and $48 \%$, respectively), compared to the respective control; after the inoculation with $X$. gardneri, plants previously treated with EPS or ASM showed an 
increase (16 and $35 \%$, respectively) in ascorbic acid concentration, when compared to the inoculated control (Figure 5B).

Moreover, the concentration of ellagic acid was altered at 5 dat, in plants sprayed with EPS non-inoculated, showing a decreased of the ellagic acid concentration around $28 \%$ while plants treated with ASM showed increase of 54\% compared to the respective control (Figure 5C). After the inoculation of the causal agent of bacterial spot, an increase of ellagic acid concentration was observed in plants treated with EPS or ASM (19 and $15 \%$, respectively), when compared to the control (Figure 5C). Seven days after the treatments, the concentration of ellagic acid had a similar behavior to the ascorbic acid. In this case, EPS or ASM, both applied in non-inoculated plants, decreased 21 and 30\%, respectively, the concentration of this phenol. In the same period, plants previously treated with ASM and inoculated with $X$. gardneri showed an increase in the ellagic acid concentration, about 27\% higher than inoculated control (Figure 5D).

\subsection{Effects of EPS on Phenylalanine Ammonia-lyase, Glutathione Reductase and Lipoxygenase Activities}

The EPS and ASM didn't change PAL activity at the 3rd day after treatment, i.e., before inoculation (Figure 6A). Nevertheless, it was observed a reduction in PAL activity in non-inoculated plants but treated with ASM or EPS at 5 dat. In this same period, a significant increase of 2.5 times in PAL activity was observed in plants sprayed with ASM and inoculated with $X$. gardneri compared to inoculated control (Figura 6B). At 7 dat, PAL activity increased more than 2.5 times in plants previously treated with EPS and challenged with $X$. gardneri (Figure $6 \mathrm{C})$.

A similar trend occurred for GR activity. Significative changes at the 3rd day after the treatments were not observed (Figure 7A). At 5 dat, plants sprayed with ASM and challenged with the pathogen showed an increase in the enzymatic activity compared to the other treatments (Figure 7B). Nonetheless, at 7 dat, plants sprayed with EPS followed by inoculation showed a higher GR activity (Figure 7C).

The EPS and ASM reduced the LOX activity at the 3 days after treatments (Figure 8A). After 5 days of the treatments, plants inoculated with the pathogen showed a significant increase in the enzymatic activity, regardless the treatment (Figure 8B). Finally, it was observed that among the inoculated plants, the plants previously sprayed with EPS (7 dat) had a higher LOX activity (Figure 8C).
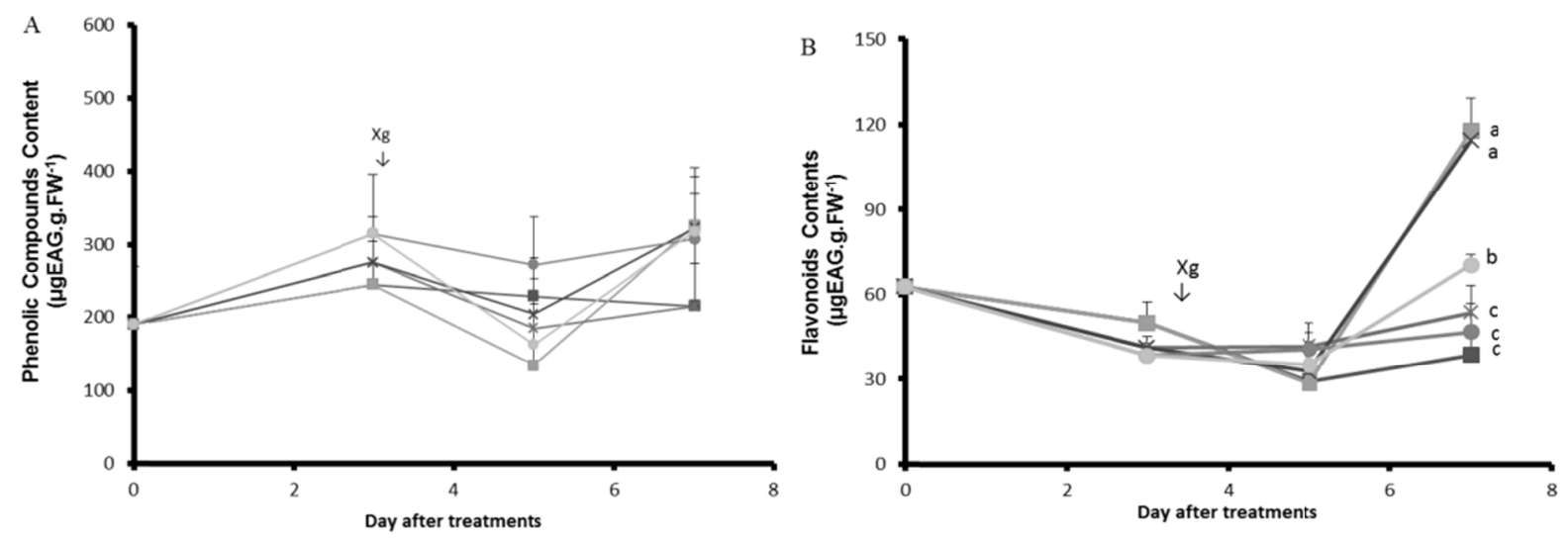

Figure 4. Content of phenolic compounds (A) and flavonoids (B) in tomato plants treated with the EPS of Lactobacillus plantarum (EPS Lac), Acibenzolar-S-Methyl (ASM) and distilled water, from plants inoculated (Inoc) or not (NI) with Xanthomonas gardneri. "Xg" indicates the inoculation with X. gardneri $\left(\mathrm{OD}_{600}=0.6\right)$. Bars represent the mean \pm standard deviation. Bars followed by different letters indicate significant difference at $5 \%$ significance by the Tukey test on time interval. ( $\square)$ Water NI, ( $\square$ ) Water Inoc, ( $\triangle$ ) EPS Lac NI, ( $\nabla)$ EPS Lac Inoc, $(\bullet)$ ASM NI and $(\bullet)$ ASM Inoc 

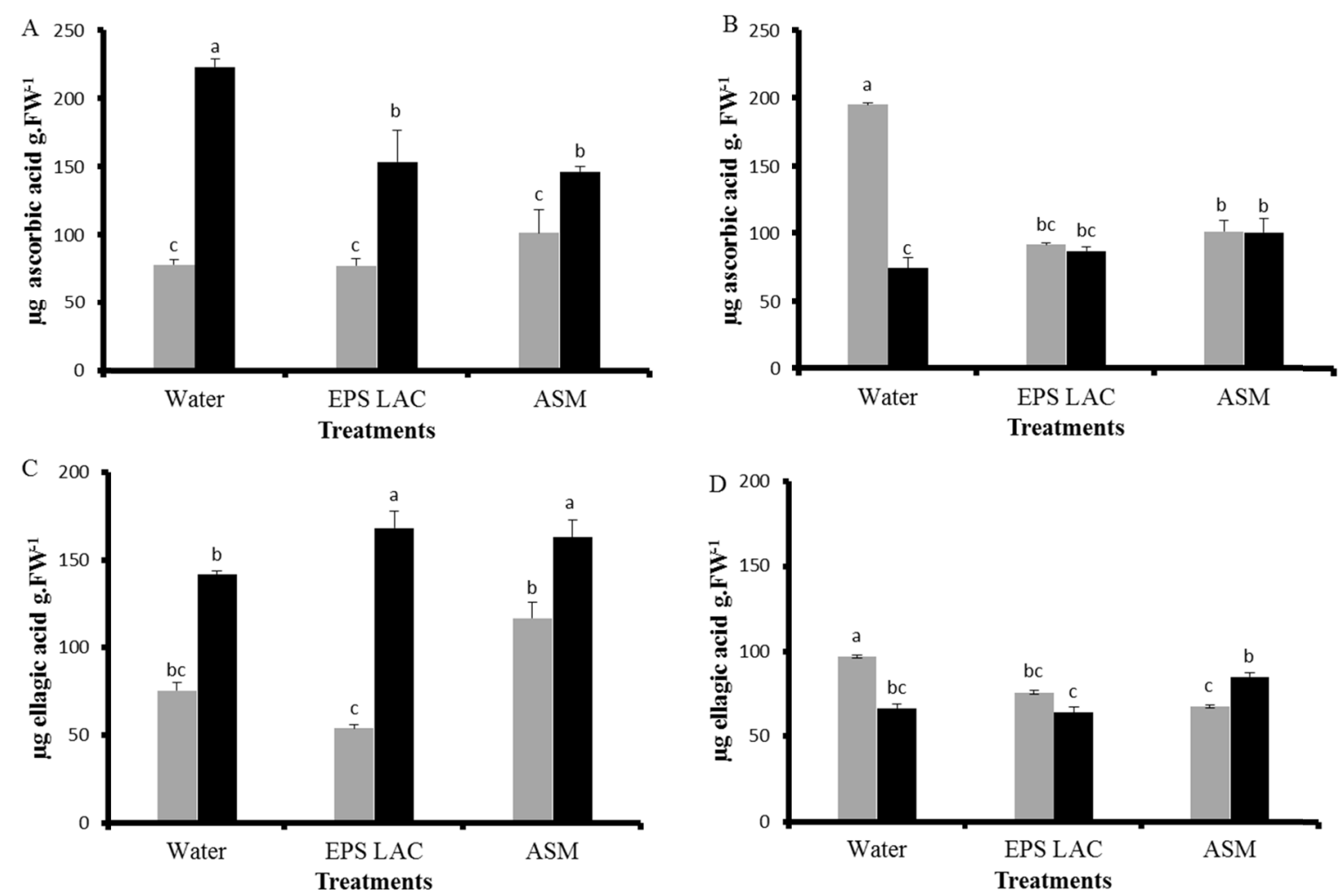

Figure 5. Concentration of ascorbic (A and B) and ellagic (C and D) acid determined by HPLC on tomato plants treated with EPS of Lactobacillus plantarum (EPS Lac), Acibenzolar-S-Methyl (ASM) or distilled water, from plants inoculated (Inoc) or not (NI) with Xanthomonas gardneri, at 5 (A and C) and 7 (B and D) days after treatment (dat). 5 and 7 dat correspond to 2 and 4 days after inoculation. Bars represent the mean \pm standard deviation. Means followed by the same letters do not differ statistically by the Tukey test $(p<0.05)$. ( $\square)$ NI and

(a) Inoc
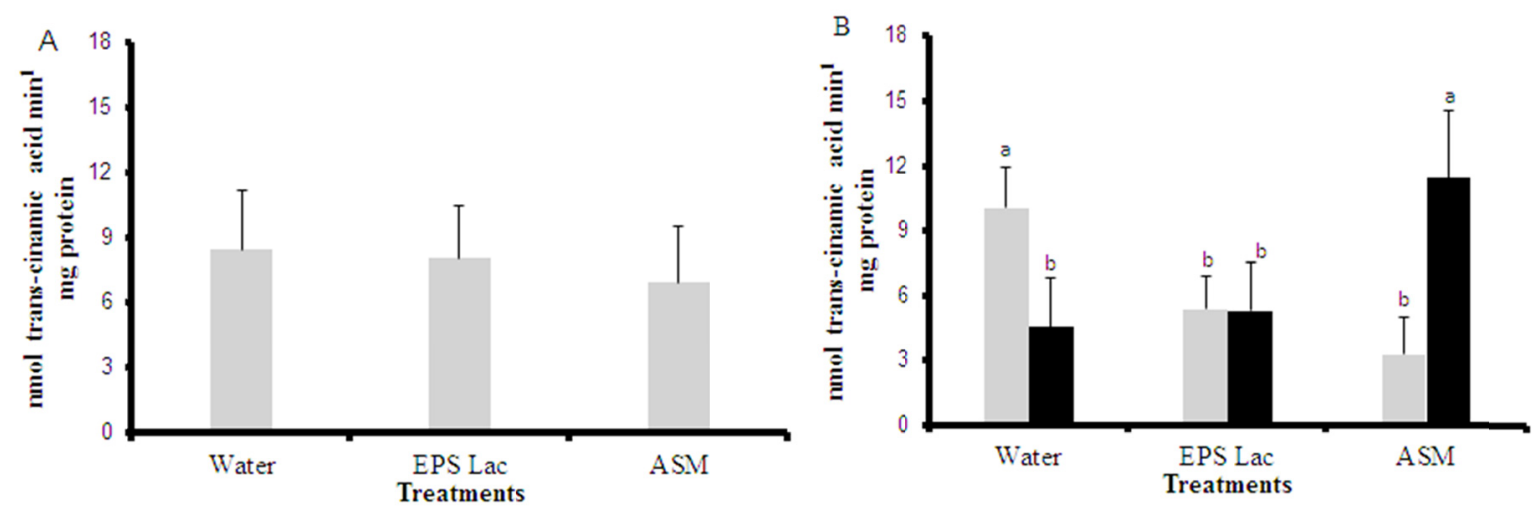


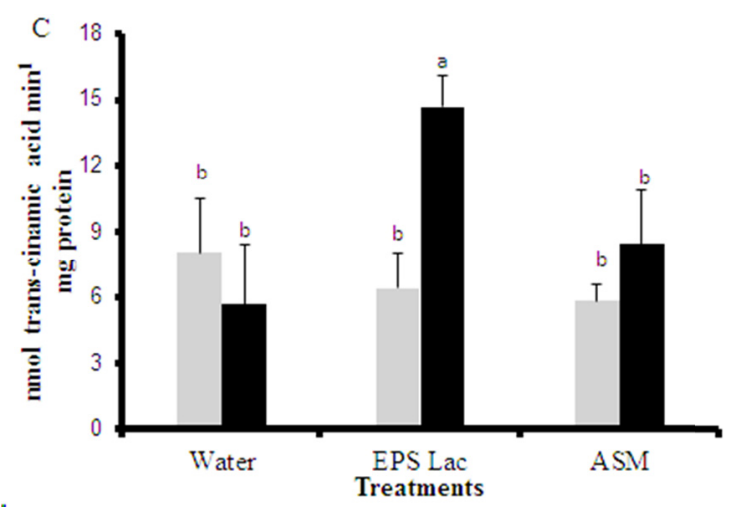

Figure 6. Phenylalanine ammonia-lyase (PAL) activity in tomato plants treated with the EPS of Lactobacillus plantarum (EPS Lac), Acibenzolar-S-Methyl (ASM) or distilled water, from plants inoculated (Inoc) or not (NI) with Xanthomonas gardneri, 3 (A), 5 (B) and 7 (C) days after the treatments (dat). 5 and 7 dat correspond to 2 and 4 days after inoculation. Bars represent the mean \pm standard deviation. Means followed by the same letters do not differ statistically by the Tukey test $(\mathrm{p}<0.05)$. ( $\mathbf{})$ NI and ( $\mathbf{a})$ Inoc
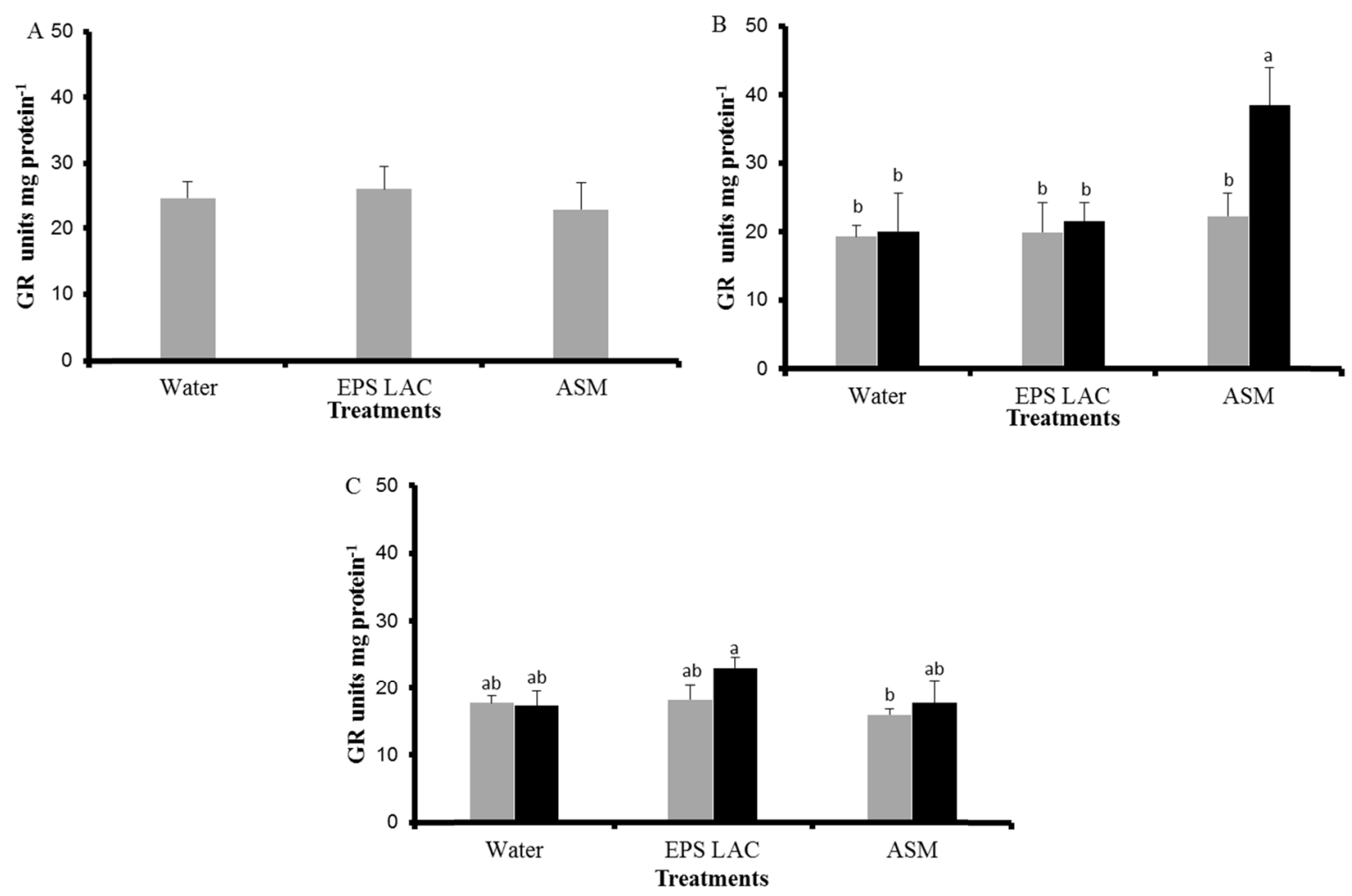

Figure 7. Glutathione redutase (GR) activity in tomato plants treated with the EPS of Lactobacillus plantarum (EPS Lac), Acibenzolar-S-Methyl (ASM) or distilled water, from plants inoculated (Inoc) or not (NI) with Xanthomonas gardneri, 3 (A), 5 (B) and 7 (C) days after the treatments (dat). 5 and 7 dat correspond to 2 and 4 days after inoculation. Bars represent the mean \pm standard deviation. Means followed by the same letters do not differ statistically by the Tukey test $(\mathrm{p}<0.05)$. ( $\bullet$ ) NI and ( $\bullet$ ) Inoc 

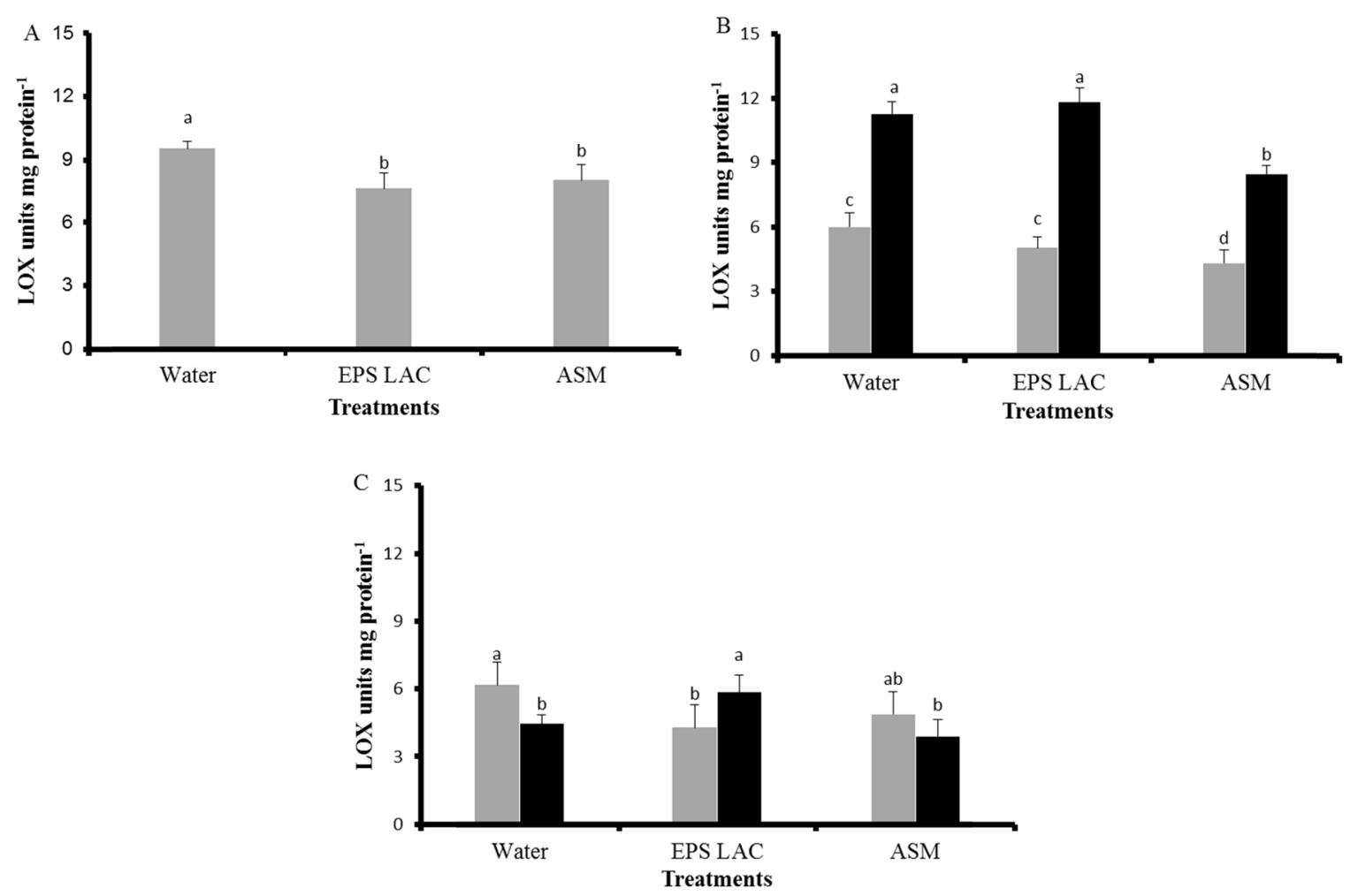

Figure 8. Lypoxigenase (LOX) activity in tomato plants treated with the EPS of Lactobacillus plantarum (EPS Lac), Acibenzolar-S-Methyl (ASM) or distilled water, inoculated (Inoc) or not (NI) with Xanthomonas gardneri, 3 (A), 5 (B) and 7 (C) days after the treatments (dat). 5 and 7 dat correspond to 2 and 4 days after inoculation. Bars represent the mean \pm standard deviation. Means followed by the same letters do not differ statistically by the Tukey test $(\mathrm{p}<0.05)$. ( $\square)$ NI and $(\square)$ Inoc

\section{Discussion}

The use of EPS derived from microorganisms presents a considerable technological application which stands out in various sectors of industry. Nonetheless, their characteristics can range depending upon the microorganism, the fermentation medium composition and growth conditions. The infrared absorption spectrum of a compound is probably its most unique physical property; therefore, the spectrum can be referred as the fingerprint of a molecule (Kacuráková \& Wilson, 2001). Polysaccharides, in general, contain a significant number of hydroxyl groups, whose broad absorption band resides around $3.000 \mathrm{~cm}^{-1}$.

Previous studies have shown the similarity of different EPS extracted from Lactobacillus species. In general, the infrared spectra show functional characteristics e.g., the $\mathrm{OH}$ group whose bands ranges between 3.700 and 3.000 $\mathrm{cm}^{-1}$, and a methyl group at around $2.924 \mathrm{~cm}^{-1}$. Polysaccharides also have high absorption at $1.200-1.000 \mathrm{~cm}^{-1}$ (corresponding to the presence of carbohydrates). The position and the intensity of the bands are specific to each polysaccharide, allowing its possible identification (Wang et al., 2008; Ai et al., 2008; Notararigo et al., 2013). Therefore, the position and intensity of the bands of the studied EPS $\left(3.425,2.931,1.048\right.$, and $\left.1.020 \mathrm{~cm}^{-1}\right)$ allowed its identification as a polysaccharide rich in carbohydrates with $\mathrm{OH}$ and $\mathrm{CH}_{3}$ groups. This result reinforces the ability of Lactobacillus to maintain the pattern of EPS production, with little variation between species of the genus and bacterial culture conditions. L. plantarum, in particular, has a great capacity to adapt to the different cultivation conditions, being able to ferment many different carbohydrates, and high tolerance to low $\mathrm{pH}$. This particularity makes the microorganism easily cultivated under controlled conditions by bioprocesses. Another advantage biotechnological use of L. plantarum stems from the abundant production of EPS naturally (Notararigo et al., 2013; Seo et al., 2015).

In this study, L. plantarum EPS reduced the severity of tomato bacterial spot when applied at 1.5 and $3.0 \mathrm{mg}$ $\mathrm{mL}^{-1}$. As far as time interval is concerned, the EPS were efficient only when applied at 3 days before the inoculation with $X$. gardneri, indicating a direct effect against the pathogen. Although, in vitro assays did not detect an antimicrobial effect of the EPS, nonetheless their bactericidal potential already been demonstrated in 
other studies against human bacteria (Li et al., 2014; Roselló et al., 2013). Therefore, it is suggested that the EPS could have acted against the pathogen through the activation of resistance mechanisms in tomato plants, even with the plant protection occurring in a short interval between EPS application and the inoculation of the plants ( 3 days), and the lacking of bacterial spot control when applied 7 days before the treatment.

The possible use of natural compounds, such as EPS of L. plantarum, for the control of diseases in plants, meets the growing demand for healthier foods. The demand for and sale of organic food commodities have increased approximately twenty-fold in recent years (APEDA, 2012). Due to this demand, the conventional disease control measures in organic production need to be combined or replaced with effective natural compounds to increased resistance in plants against pathogens.

The EPS capacity to control the bacterial spot of tomato may be related to the plant's ability in recognize molecules from microorganisms (MAMP's). This recognition is known to occur by the receptors located on the cell membrane surface or inside the cell, which will trigger a signal transduction cascade, leading to the activation of defense mechanisms. This type of defense allows plants to respond quickly and efficiently to several pathogens (Zhang \& Zhou, 2010, Shang et al., 2007).

The eliciting effects of bacterial EPS in different pathosystems were previously documented. In barley plants, Antoniazzi et al. (2008) observed a reduction of $75 \%$ in the disease severity caused by Bipolaris sorokiniana. This value was very similar to those observed to the fungicide application. In that study, the control of the disease was attributed to the increase of 1,3-glucanase activities and the increase of phenolic compound levels in plants treated with EPS.

In coffee plants, the application of EPS extracted from Xanthomonas spp. (xanthan gum) and commercial xanthan gum were able to induce plant resistance against Hemileia vastatrix, reducing the disease severity by 92\% (Guzzo et al., 1996). These effects were also observed in studies with tomato plants against $X$. gardneri (Luiz et al., 2015) and in studies with EPS extracted from $X$. campestris, which induced resistance in wheat plants against Bipolaris bicolor, Bipolaris sorokiniana, and Drechslera tritici-repentis (Bach, 1997; Bach et al., 2003). In the present study, the activation of defense mechanisms have been evidenced by the changes in absorbance rates of leaf extract, concentration of phenolics, such as ascorbic and ellagic acid, and also in PAL and GR activities of plants treated with EPS or ASM.

In general, the changes observed in the range of $285-325 \mathrm{~nm}$ are related to the class of phenolic compounds, indicating a change in the defense mechanisms in treated plants, especially after the inoculation with the pathogen. Although no changes were observed in the total phenolic content using the reagent Folin-Ciocalteu, probably due the low method sensibility, with the use of a more sensitive technique (HPLC), differences in the concentration of phenolics were found, such as ascorbic and ellagic acid. Phenolic compounds have a great importance in the defense of plants, once after elicitation, several phenolic compounds are oxidized and transformed into antimicrobial compounds, such as quinones (Vaughn \& Duke, 1984). In this sense, the presence of ascorbic acid and ellagic acid ensures a reduction in the oxidative damage within the cell, once they act as non-enzymatic antioxidants. Meanwhile, the biosynthesis and regulation of these compounds are directly involved with the activity of phenylalanine ammonia lyase (PAL).

Increased PAL activity is often associated with an increased phenylpropanoid concentration, which would lead to an association with phenolic compound accumulation, since phenylalanine and phenols are both produced by shikimic acid pathway. This enzyme acts in the conversion of L-phenylalanine to trans-cinnamic acid, resulting in several phenolic compounds, such as phytoalexins, flavonoids, and lignin, which confers resistance to the cell wall and act as a signal to the plant defense responses against biotic and abiotic stresses (Gerasimova et al., 2005; Latha et al., 2009).

In this study, EPS and ASM increased PAL activity in inoculated plants. However, plants treated with EPS showed this increase later (4 days after challenge or 7 dat), compared to those plants treated with ASM, in which the increase in activity PAL was observed 2 days after the inoculation ( 5 dat). Similar trend was observed for the activity of glutathione reductase (GR), where plants treated with the commercial inducer (ASM) showed a faster increase of the enzymatic activity in response to the pathogen when compared to EPS. This may be related to the difference observed in the disease control level provided by the products: ASM activated FAL and GR earlier and more intensely controlled the disease compared to EPS (around $90 \%$ against $72 \%$ ).

GR is an important part of the antioxidant system. In general, the whole set that involves glutathione molecules in plants is related to the tolerance increase to oxidative stress (Sharma, 2012; Sharma \& Dubey, 2007). Ge et al. (2013) for example, reported that in melon cultivars resistant to Colletotrichum lagenarium, enzymatic antioxidants such as glutathione reductase and ascorbate peroxidase, and non-enzymatic molecules such as 
glutathione (reduced form) and ascorbic acid, are widely expressed during the defense of the plant. These compounds, along with PR proteins are essential for the defense of melon seedlings, allowing an efficient protection against the pathogen infection. Besides, the glutathione and ascorbic acid are directly involved in the ascorbate-glutathione cycle reactions, and are crucial for the preservation of many metabolic processes of the cell (Drazkiewicz et al., 2003).

The application of EPS in tomato plants also triggered an increase the LOX activity, unlike the commercial inducer. LOX is part of another metabolic pathway, the pathway of jasmonic acid (JA). JA is a phytohormone directly involved in the plant defense responses against stress, and used as a stress indicator. Choudhary (2011) and Ferraz et al. (2014) reported that the application of biotic inducers able to stimulate LOX activity, contributed to the resistance of tomato plants against Fusarium sp., and also in soybean plants against Macrophomina phaseolina. In both cases, the disease control was attributed to the activation of JA pathway. In this sense, the control of tomato bacterial spot provided by the application of EPS could be the result of the activation of more than one metabolic pathway, unlike the ASM, compound similar to salicylic acid, which primarily triggers those metabolites from the phenylpropanoid pathway (Oostendorp et al., 2001).

It is well known that jasmonic and salicylic acids are usually referred as antagonistic hormones acting against different kinds of pathogens i.e., the plant starts to increase the levels of salicylic acid (against biotrophic pathogens) or jasmonate (against necrotrophic pathogens), promoting specific defense responses, focused on the type of pathogen detected. Though, in some cases, these hormones can occur and act synergistically, e.g., when present in low concentrations in healthy tissues, performing nonspecific immune response (Fu \& Dong, 2013). For example, Davidsson et al. (2013) described that the simultaneous activation of salicylate and jasmonate pathways appear to be crucial for the attenuation of virulence of Pectobacterium spp. In our study, considering that Xanthomonas is a hemibiotrophic pathogen, initially forming an association with living cells of the host, thereafter killing the plant cell to use the nutrients from this process (Chan \& Goodwin, 1999), the use of an inducer capable of stimulate both pathways, as we observed for EPS, can be an attractive way for control this bacterial disease.

Also, the obtained results suggest that EPS is able to induce resistance on tomato plants by pre-conditioning them against the pathogen, because plants previously treated with the biopolymer had increased defense mechanisms only after bacterial challenge (priming effect) (Cools \& Ishii, 2002; Conrath et al., 2002). In a different way, we observed that the application of ASM increased the content of phenolic acids in tomato plants before the arrival of the pathogen, which could generate costs for the plant at the end of the process. Some studies indicated that ASM, depending of the dose, number of applications, plant growth stage and pathogen pressure, may cause a reduction in the yield, and a delaying on fruit maturity, indicating the efforts of the cells to increase proteins related to defense rather than those related to cell proliferation (Suzuki et al., 2006; Walters et al., 2013).

\section{Conclusions}

The findings indicate that the EPS of $L$. plantarum were able to decrease the severity of tomato bacterial spot by pre-conditioning the plant, and by increasing the compounds and enzymes related to the plant defense from different pathways. The results provide a basis for further studies in a way that the Lactobacillus EPS can be used in agriculture in a few years as an option for the disease control, especially in organic farming.

\section{Acknowledgements}

The authors acknowledge the Coordination of Development of High Education Personnel (CAPES) for awarding fellowships, Sakata for the bacterial isolate, and to Dr. Alice M. Quezado-Duval, EMBRAPA, for the identification of the pathogen.

\section{References}

Abbasi, P. A., Khabbaz, S. E., Weselowski, B., \& Zhang, L. (2015). Occurrence of copper-resistant strains and a shift in Xanthomonas spp. causing tomato bacterial spot in Ontario. Can J Microbiol., 61(10), 753-61. https://dx.doi/10.1139/cjm-2015-0228

Ai, L., Zhang, H., Guo, B., Chen, W., Wu, Z., \& Wu, Y. (2008). Preparation, partial characterization and bioactivity of exopolysaccharides from Lactobacillus casei LC2W. Carbohyd Polym., 74, 353-357. https://dx.doi/10.1016/j.carbpol.2008.03.004

Antoniazzi, N., Deschamps, C., \& Bach, E. E. (2008). Effect of xanthan gum and allicin as elicitors against Bipolaris sorokiniana on barley in field experiments. $J$ Plant Dis Protec., 115, 104-107 https://dx.doi/10.1007/BF03356248 
APEDA (Agricultural and Processed Food Products Export Development Authority). (2012-2014). Issue of Phytosanitary Certificates Mandatory for Export of Horticultural produts to EU. Ministry of Commerce and Industry, Govenment of India, New Delhi. Retrieved from http//www.apeda.gov.in/apedawebsite/ Announcements/Ministry_of_Agriculture.html

Araújo, E. R., Ferreira, M. A. S. V., \& Quezado-Duval, A. M. (2013). Specific primers for Xanthomonas vesicatoria, a tomato bacterial spot causal agent. Eur J Plant Pathol., 137, 5-9. https://dx.doi/10.1007/ s10658-013-0225-4

Axelrod, B. C., Cheesbrough, T. M., \& Laasko, S. L. (1981). Lipoxygenase from soybean. Method Enzymol., 71, 441-451.

Bach, E. E. (1997). Morphological distinction and isozyme of Bipolaris spp. and Drechslera tritici-repentis in wheat: Biochemical aspects in the interactions and resistance induction (Dissertation, University of Sao Paulo).

Bach, E. E., Barros, B. C., \& Kimati, H. (2003). Induced resistance against Bipolaris bicolor, Bipolaris sorokiniana and Drechslera tritici-repentis in wheat leaves by xantham gum and heat-inactivate conidia suspension. J Phytopathol., 151, 411-418. https://dx.doi/10.1046/j.1439-0434.2003.00742.x

Baque, M. A., Mho, S. H., Lee, E. J., Zhong, J. J., \& Paek, K. Y. (2012). Production of biomass and useful compounds from adventitious roots of high-value added medicinal plants using bioreactor. Biotechnol Adv., 30, 1255-1267. https://dx.doi/10.1016/j.biotechadv.2011.11.004

Camelini, C. M., Gomes, A., Cardozo, F. T. G. S., Simões, C. M. O., Rossi, M. J., Giachini, A. J., ... De Mendonça, M. M. (2013). Production of polysaccharide from Agaricus subrufescens Peck on solid-state fermentation. Appl Microbiol Biot., 97, 123-133. https://dx.doi/10.1007/s00253-012-4281-z

Carlberg, C., \& Mannervik, B. (1985). Glutathione reductase. Method Enzymol., 113, 488-495.

Chan, J. W. Y. F., \& Goodwin, P. H. (1999). The molecular genetics of virulence of Xanthomonas campestris. Biotechnol Adv., 17, 489-508. https://dx.doi/10.1016/S0734-9750(99)00025-7

Choudhary, D. K. (2011). Plant growth-promotion (PGP) activities and molecular characterization of rhizobacterial strains isolated from soybean (Glycine max L. Merril) plants against charcoal rot pathogen, Macrophomina phaseolina. Biotechnol Lett., 33, 2287-2295. https://dx.doi/10.1007/s10529-011-0699-0

Conrath, U., Pieterse, C. M. J., \& Mauch-Mani, B. (2002). Priming in plant-pathogen interactions. Trends Plant Sci., 7, 210-216. https://dx.doi/10.1016/S1360-1385(02)02244-6

Cools, H. J., \& Ishii, H. (2002). Pre-treatment of cucumber plants with acibenzolar-S-methyl systemically primes a phenylalanine ammonia lyase gene (PAL1) for enhanced expression upon attack with a pathogenic fungus. Physiol Mol Plant P., 61, 273-282. https://dx.doi/10.1006/pmpp.2003.0439

Coqueiro, D. S., \& Di Piero, R. M. (2011). Antibiotic activity against Xanthomonas gardneri and protection of tomato plants by chitosan. $J$ Plant Pathol., 93, 337-344. https://dx.doi/10.4454/jpp.v93i2.1188

Davidsson, P. R., Kariola, T., Niemi, O., \& Palva, E. T. (2013). Pathogenicity of and plant immunity to soft rot pectobacteria. Front Plant Sci., 4, 1-13. https://dx.doi/10.3389/fpls.2013.00191

Dimitri, C., \& Oberholtzer, L. (2009). Marketing US Organic Foods: Recent Trends from Farms to Consumers. ERS, Economic Research Service/USDA.

Drazkiewicz, M., Skórzyńska-Polit, E., \& Krupa, Z. (2003). Response of the ascorbate-glutathione cycle to excess copper in Arabidopsis thaliana (L.). Plant Sci., 164, 195-202. https://dx.doi/10.1016/S0168-9452 (02)00383-7

Ebrahim, S., Usha, K., \& Singh, B. (2011). Pathogenesis related (PR) proteins in plant defense mechanism. Science against microbial pathogens: Communicating current research and technological advances (pp. 1043-1054).

FAO (Food and Agriculture Organization of the United Nations). (2014). FAOSTAT. Retrieved January 10, 2014, from http://faostat.fao.org/site/567/default.aspx\#ancor

Ferraz, H. G. M., Resende, S., Silveira, P. R., Andrade, C. C. L., Milagres, E. A., Oliveira, J. R., \& Rodrigues, F A. (2014). Rhizobacteria induces resistance against Fusarium wilt of tomato by increasing the activity of defense enzymes. Bragantia, 73, 274-283. https://dx.doi/10.1590/1678-4499.0124

Ferreira, D. F. (2003). SISVAR, 4.3 (Build 45). Federal University of Lavras, Minas Gerais, Brazil. 
Feussner, I., \& Wasternack, C. (2002). The lipoxygenase pathway. Annu Rev Plant Biol., 53, $275-297$. https://dx.doi/10.1146/annurev.arplant.53.100301.135248

Fu, Z. Q., \& Dong, X. (2013). Systemic acquired resistance: turning local infection into global defense. Annu Rev Plant Biol., 64, 839-863. https://dx.doi/10.1146/annurev-arplant-042811-105606

Gao, Q. M., Zhu, S., Kachroo, P., \& Kachroo, A. (2015). Signal regulators of systemic acquired resistance. Front Plant Sci., l, 1-12. https://dx.doi/10.3389/fpls.2015.00228

Ge, Y., Bi, Y., \& Guest, D. I. (2013). Physiological and molecular plant pathology defence responses in leaves of resistant and susceptible melon (Cucumis melo L.) cultivars infected with Colletotrichum lagenarium. Physiol Mol Plant P., 81, 13-21. https://dx.doi/10.1016/j.pmpp.2012.09.002

Gerasimova, N. G., Pridvorova, S. M., \& Ozeretskovskaya, O. L. (2005). Role of 1-phelylalanine ammonia lyase in the induced resistence and susceptibily of potato plants. Appl. Biochem. Micro., 41, 103-105 https://dx.doi/10.1007/s10438-005-0019-3

Guzzo, S. D., Back, E. A., Martins, E. M., \& Moraes, W. B. (1993). Crude expolysaccarides (EPS) from Xanthomonas campestris pv. maniohtis, Xanthomonas campestris pv. campestris and commercial xanthan gumas inducers of protection in coffee plants against Hemileia vastatrix. J Phytopathol., 139, 119-128.

Huang, T. K., \& Mcdonald, K. A. (2009). Bioreactor engineering for recombinant protein production in plant cell suspension cultures. Biochem Eng J., 45, 168-184. https://dx.doi/10.1016/j.bej.2009.02.008

Jones, J. B., Lacy, G. H., Bouzar, H., Stall, R. E., \& Schaad, N. W. (2004). Reclassification of the Xanthomonads associated with bacterial spot disease of tomato and pepper. Syst Appl Microbiol., 27, 755-762. https://dx.doi/10.1078/0723202042369884

Kacuráková, M., \& Wilson, R. H. (2001). Developments in mid-infrared FT-IR spectroscopy of selected carbohydrates. Carbohyd Polym., 44, 291-303. https://dx.doi/10.1016/S0144-8617(00)00151-X

Kofalvi, S. A., \& Nassuth, A. (1995). Influence of wheat streak mosaic virus infection on phenylpropanoid metabolism and the accumulation of phenolics and lignin in wheat. Physiol Mol Plant P., 47, 365-377. https://dx.doi/10.1006/pmpp.1995.1065

Latha, P., Anand, T., Rappathi, N., Prakasam, V., \& Samiyappan, R. (2009). Antimicrobial activity of plant extracts and induction of systemic resistance in tomato plants by mixtures of PGPR strains and Zimmu leaf extract against Alternaria solani. Biol Control., 50, 85-93. https://dx.doi/10.1016/j.biocontrol.2009.03.002

Laws, A., Gu, Y., \& Marshall, V. (2001). Biosynthesis, characterisation, and design of bacterial exopolysaccharides from lactic acid bacteria. Biotechnol Adv., 19, 597-625. https://dx.doi/10.1016/ S0734-9750(01)00084-2

Leemhuis, H., Pijning, T., Dobruchowskaa, J. M., Van Leeuwena, S. S., Kralj, S., \& Dijkstrab, B. W. (2013). Three-dimensional structures, reactions, mechanism, $\alpha$-glucan analysis and their implications in biotechnology and food applications. $J$ Biotechnol., 163, 250-272. https://dx.doi/10.1007/ s00253-012-3943-1

Li, S., Huang, R., Shah, N. P., Tao, X., Xiong, Y., \& Wei, H. (2014). Antioxidant and antibacterial activities of exopolysaccharides from Bifidobacterium bifidum WBIN03 and Lactobacillus plantarum R315. J Dairy Sci., 97, 7334-43. https://dx.doi/10.3168/jds.2014-7912

Luiz, C., Felipini, R. B., Costa, M. E. B., \& Di Piero, R. M. (2012). Polysaccharides from aloe barbadensis reduce the severity of bacterial spot and activate disease-related proteins in tomato. J Plant Pathol., 94, 387-393. https://dx.doi/10.4454/JPP.FA.2012.046

Luiz, C., Rocha Neto, A. C., \& Di Piero, R. M. (2015). Resistance to Xanthomonas gardneri in tomato leaves induced bypolysaccharides from plant or microbial origin. J Plant Pathol., 97, 119-127. https://dx.doi/10.4454/JPP.V97I1.029

Mahapata, S., \& Banerjee, D. (2013). Fungal Exopolysaccharide: Production, Composition and Applications. Microbiology Insights, 6, 1-16. https://dx.doi/10.4137/MBI.S10957

Mccue, P., Zheng, Z., Pinkham, J. L., \& Shetty, K. (2000). A model for enhanced pea seedling vigour following low $\mathrm{pH}$ and salicylic acid treatments. Biochemistry, 35, 603-613. https://dx.doi/10.1016/S0032-9592 (99)00111-9 
Mello, S. C. M., Takatsu, A., \& Lopes, C. A. (1997). Diagrammatic scale for assessment of tomato bacterial spot. Braz Phytopathol., 22, 447-448.

Notararigo, S., Nacher-Vazquez, M., Ibarburu, I., Werning, M. L., De Palencia, P. F., Duenas, M. T., ... Prieto, A. (2013). Comparative analysis of production and purification of homo- and hetero-polysaccharides produced by lactic acid bacteria. Carbohyd Polym., 93, 57-64. https://dx.doi/10.1016/j.carbpol.2012.05.016

Obradovic, A., Jones, J. B., Momol, M. T., Balogh, B., \& Olson, S. M. (2004). Management of tomato bacterial spot in the field by foliar application of bacteriophages and SAR inducers. Plant Dis., 88, 736-740. https://dx.doi/10.1094/PDIS.2004.88.7.736

Oostendorp, M., Kunz, W., Dietrich, B., \& Staub, T. (2001). Induced disease resistance in plants by chemicals. Eur J Plant Pathol., 107, 19-28. https://dx.doi/10.1023/A:1008760518772

Potnis, N., Timilsina, S., Strayer, A., Shantharaj, D., Barak, J. D., Paret, M. L., ... Jones, J. B. (2015). Bacterial spot of tomato and pepper: Diverse Xanthomonas species with a wide variety of virulence factors posing a worldwide challenge. Mol. Plant Pathol., 16, 907-920. https://dx.doi/10.1111/mpp.12244

Quezado-Duval, A. M., Leite Junior, R. P., Lopes, C. A., Lima, M. F., \& Camargo, L. E. A. (2005). Diversity of Xanthomonas spp. associated with bacterial spot of processing tomatoes in Brazil. Acta Hortic., 695, 101-108. https://dx.doi/10.17660/ActaHortic.2005.695.11

Raiola, A., Rigano, M. M., Calafiore, R., Frusciante, L., \& Barone, A. (2014). Enhancing the human-promoting effects of tomato fruit for bofortified food. Mediators Inflamm, 1-16. https://dx.doi/10.1155/2014/139873

Roselló, G., Bonaterra, A., Francés, J., Montesinos, L., Badosa, E., \& Montesinos, E. (2013). Biological control of fire blight of apple and pear with antagonistic Lactobacillus plantarum. Eur J Plant Pathol., 137, 621-633. https://dx.doi/10.1007/s10658-013-0275-7

Salazar, S. M., Grellet, C. F., Chalfoun, N. R., Castagnaro, A. P., \& Díaz Ricci, J. C. (2013). Avirulent strain of Colletotrichum induces a systemic resistance in strawberry. Eur J Plant Pathol., 135, 877-888. https://dx.doi/10.1007/s10658-012-0134-y

Seo, B., Bajpai, V. K., Rather, I. A., \& Park, Y. (2015). Partially purified exopolysaccharide from Lactobacillus plantarum YML009 with total phenolic content, antioxidant and free radical scavenging efficacy. Indian $J$ Pharm Educ Res., 49, 282-292. https://dx.doi/10.5530/ijper.49.4.6

Shan, L., He, P., \& Sheen, J. (2007). Endless Hide-and-Seek: Dynamic co-evolution in plant-bacterium warfare. J. Integr. Plant Biol., 49, 105-111. https://dx.doi/10.1111/j.1744-7909.2006.00409.x

Sharma, P., \& Dubey, R. S. (2005). Drought induces oxidative stress and enhances the activities of antioxidant enzymes in growing rice seedlings. Plant Growth Regul., 46, 209-221 https://dx.doi/10.1007/s10725005-0002-2

Sharma, P., Jha, A. B., Dubey, R. S., \& Pessarakli, M. (2012). Reactive oxygen species, oxidative damage, and antioxidative defense mechanism in plants under stressful conditions. J. Bot., 1-26. https://dx.doi/10.1155/ $2012 / 217037$

Silva, C. M. M. S., \& Fay, E. F. (2006). Environmental impact of the fungicide metalaxyl (p. 96). Jaguariuna: Embrapa Environment.

Suzuki, K., Nishiuchi, T., Nakayama, Y., Ito, M., \& Shinshi, H. (2006). Elicitor-induced down-regulation of cell cycle-related genes in tobacco cells. Plant Cell Environ., 29, 183-191. https://dx.doi/10.1111/j.1365-3040. 2005.01411.x

Tian, S., Wan, Y., Qin, G., \& Xu, Y. (2006). Induction of defense responses against Alternaria rot by different elicitors in harvested pear fruit. App. Microbiol. Biot., 70, 729-734. https://dx.doi/10.1007/ s00253-005-0125-4

Vaughn, K. C., \& Duke, S. O. (1984). Function of polyphenol oxidase in higher plants. Physiol. Plantarum., 60, 106-112. https://dx.doi/10.1111/j.1399-3054.1984.tb04258.x

Walters, D. R., Ratsep, J., \& Havis, N. D. (2013). Controlling crop diseases using induced resistance: Challenges for the future. J. Exp. Bot., 64, 1263-1280. https://dx.doi/10.1093/jxb/ert026

Wang, Y., Ahmed, Z., Feng, W., Li, C., \& Song, S. (2008). Physicochemical properties of exopolysaccharide produced by Lactobacillus kefiranofaciens ZW3 isolated from Tibet kefir. Int. J. Biol. Macromol., 43, 283-288. https://dx.doi/10.1016/j.ijbiomac.2008.06.011 
Zhang, J., \& Zhou, J. M. (2010) Plant immunity triggered by microbial molecular signatures. Mol Plant., 5, 783-793. https://dx.doi/10.1093/mp/ssq035

\section{Abbreviations}

EPS, exopolysaccharides; PAL, phenylalanine ammonia-lyase; GR, glutathione reductase; LOX, lipoxygenase; GSH, reduced glutathione; GSSG, oxidized glutathione; JA, jasmonic acid; MAMPs, microbe-associated molecular patterns; ASM, Acibenzolar-S-Methyl; HPLC, High performance liquid chromatography; FTIR, Fourier transform infrared spectroscopy; OD, optical density; CFU, colony-forming units; DAT, day after treatmens; DAI, day after inoculation.

\section{Copyrights}

Copyright for this article is retained by the author(s), with first publication rights granted to the journal.

This is an open-access article distributed under the terms and conditions of the Creative Commons Attribution license (http://creativecommons.org/licenses/by/4.0/). 